\title{
Til billedet af Kafka
}

Klaus Wagenbach, Franz Kafka - billeder fra hans liv, oversat af Judyta Preis og Jørgen Herman Monrad, København: Forlaget Vandkunsten, 2009, 253 sider.

Niels Bokhove \& Marijke van Dorst, udg., 'Einmal ein großer Zeichner' - Franz Kafka als bildender Künstler, Prag: Vitalis, 2011, 110 sider.

Der er for relativt nylig udkommet to billedbårne Kafka-bøger: en dansk oversættelse af Klaus Wagenbachs billedbiografi Franz Kafka - billeder fra hans liv og en tysk, forbedret udgave af en oprindeligt hollandsk udgivelse af Kafkas tegninger, 'Einmal ein großer Zeichner' - Franz Kafka als bildender Künstler.

Sidstnævnte indeholder 41 tegninger, hvoraf en del er kendt i forvejen, blandt andet fra Wagenbach. Hver tegning - Kafka kaldte selv sin tegning en "personlig billedskrift" - er i denne udgivelse trykt på en selvstændig side og ledsages på modstående side af et med tegningen korresponderende tekststykke af Kafka, dagbogsoptegnelser, breve, litterære skitser, uddrag af fortællinger og romaner. I flere tilfælde har Kafka lavet tegningerne under, over, ved siden af eller ind i et tekststykke på et manuskriptark, og her ledsages de af den pågældende tekst, fx hører en tegning af en hestekusk sammen med en tekstbid fra "Beskrivelse af en kamp". Derudover er bogen forsynet med et efterord, en grundig fortegnelse over tegningernes titel, teknik, format, kilde og datering, originalens lokalitet og stedet for første offentliggørelse, samt en fortegnelse over nævnte, men ikke tilgængelige tegninger (ni i alt), optryk af forlæggene til tegningerne i de tilfælde, hvor der har været et sådant, og en udførlig bibliografi over det anvendte materiale. En aldeles sober redaktion med andre ord.

Hovedparten er fine, skævt naive stiliserede tegninger af figurer i forskellige positioner eller bevægelser - kroppe i (tomme) rum, figurer placeret på ellers blanke ark, hvorved den tomme baggrund, af hvilken de træder frem, accentueres. Der er de sorte figurer og så denne tomme, ubeskrevne hvidhed. De første syv antageligt blæktegninger - der også er de mest kendte af Kafkas tegninger, brugt som omslagsillustrationer og herhjemme blandt andet som illustrationer til de Efterladte fortællinger (Gyldendal 2008) - forestiller næsten alle silhuet-lignende ensomme mandlige figurer i en statisk situation. Kroppene er mættet af sort blæk, mens de fleste hænder og nogle hoveder er fremstillet ved en tegnet kontur og derfor er hvide som baggrunden: en tænker på en stol med hovedet hvilende på højre hånd; en bortvendt mand med spredte ben og hænderne samlet på ryggen omkranset af et hegn, som danner en trekant; en tilsyneladende stillestående mand med spadserestok i højre hånd og venstre hånd støttende på en plan flade; en mand på en stol, som ligger foroverbøjet ind over et bord med hovedet på sine hænder, bord og stol er underligt uforankret i rummet; en bortvendt mand med krydsede ben foran et stort stående - ikke-reflekterende - spejl på hvis ene stander han hviler sin højre hånd; en siddende mand i profil med nedsænket, foroverbøjet hoved og et nedadvendt sort øje, det venstre ben ligger udstrakt, mens det højre er bøjet, og armene hviler på hver sit ben; og endelig en fremadlænet, langstrakt fægter en garde. Måske med undtagelse af den sidste forekommer alle disse horisontløse tegninger, som Max Brod kaldte "die 
schwarzen Marionetten an unsichtbaren Faden" (de sorte marionetter i usynlig snor), at beskrive mennesker henvist til situationer, de ønsker at komme ud af; til steder, de vil væk fra - de signalerer det "væk-herfra", weg-von-hier, som Judith Butler i nærværende nummer af Passage udpeger som målet for fortælleren af "Opbruddet" og måske også for Kafka. Der er en tyngende udlængsel, en løsrivelsestrang, i tegningerne, men måske også resignerende forsøg på accept af henvistheden til dette-her.

Der er også en række mere humoristiske motiver og situationer, $\mathrm{fx}$ en betuttet smokingklædt mand blandt tre fabeldyr; en spankulerende protestdemonstration med vinden i ryggen; og en karikaturagtig fremstilling af en tigger med hatten i hånden og en fornem beskytter med fremskudt, overdimensioneret bryst, som alle appellerer mere til smilebåndet end udfrielsestrangen. En tredje kategori er de intense og ekspressionistisk inspirerede tegninger og skitser af en maltrakteret mand ved et bord med tilskuere; en gnaven mand med sammenknebne øjne, store ører, ingen hals og en stor monolitisk overkrop i sort jakkesæt; en vild dranker hængende over et bord med et vinglas; og to ventende figurer, en lille sort og en stor hvid, som sidder og stirrer tomt hen for sig ud af tegningen. En fjerde kategori udgøres af tre mere konturløse blyantsportrætter af Dora Diamant, den læsende moder Kafka og et selvportræt med midterskilning, antagelig efter et fotografi fra 1910. Endelig er der en række skitser og øvelser med forskellige motiver, blandt andet Goethes havehus, hvoraf flere fremstår tilsyneladende ikke tilstræbt ubehjælpsomme, herunder en rudimentær tegning af en fontæne i San Margherita, hvis udførelse ikke forekommer at retfærdiggøre publikation af andre årsager, end at den kommer fra Kafkas hånd.

De oftest stærkt reducerede og stramt komponerede tegninger virker således som billedmæssige ækvivalenter til Kafkas prosatekster, fx Mann zwischen Gittern, mens andre synes mere ekspressionistisk influeret, fx Malträtierter Mann vor einem Tisch, mit Zuschauern, med mindelser om George Grosz (Kafka opfattede efter sigende dennes tegninger som "tegnet litteratur") og om Der blaue Reiter og en tidlig Paul Klee og Vasilij Kandinskij samt den jødiske Marc Chagalls fabulerende, svagt mystiske billedsprog, og nogle helt tredje befinder sig et sted mellem en optagethed af en med futurismen beslægtet bevægelsesinteresse og Jugendstilens organiske former, fx Läufer og Drei Läufer. Herved bærer tegningerne også præg af Kafkas orientering mod de forskellige billedkunstneriske strømninger i hans samtid - ligesom hans interesse for japansk kunst heller ikke fornægter sig.

Den henvisthed til en situation, man ønsker at undslippe, som mange af figurerne i tegningerne giver indtryk af, synes ikke overraskende i flere tilfælde også at gælde Kafkas eget liv. Således skriver Walter Benjamin i sit essay til tiårsdagen for Kafkas død om det kendte barndomsfotografi fra

46 et af disse atelierer fra det nittende århundrede, der med deres draperier og palmer, gobeliner og staffelier befinder sig så tvetydigt mellem torturkammer og tronsal. Der står den knap seksårige dreng i en slags vinterlandskab, iklædt et trangt, nærmest ydmygende barneantræk overlæsset med snore. Palmeblade rager op i baggrunden. Og som gjaldt det om at gøre disse polstrede troper endnu mere lumre og kvalmende, holder modellen i venstre hånd en overmåde stor hat med brede skygger, sådan som spanierne bruger det. Umådelig sørgmodige øjne behersker dette landskab, som er forudbestemt for dem, og 
som et stort øres tragt lytter opmærksomt til. (Oversat af Peter Kirkegaard i Fortælleren og andre essays, Kbh.: Gyldendal, 1996, s. 96)

Det omtalte fotografi optræder også i Kafka-kenderen Klaus Wagenbachs bog med fotografier fra Kafkas liv indsamlet gennem fem årtier, faktisk indeholder den samtlige kendte fotografier af Kafka! Med sine omkring 600 kronologisk ordnede fotografier og postkort af familie, venner, kærester, arbejdsgivere, kolleger, familiens boliger og barndomshjem, landskaber, bygninger, arbejdssteder, byrum, kursteder, breve, tegninger med mere udgør bogen en port til den centraleuropæiske jødiske kultur i slutningen af det 19. og begyndelsen af det 20. århundrede, en kultur der for en stor dels vedkommende gik tabt med Første Verdenskrig og mere endegyldigt med Anden, i hvilken Kafkas tre yngre søstre Elli, Valli og Ottla blev myrdet i Auschwitz. Bogen er forsynet med et kort forord og små introducerende tekster til de ni perioder, Wagenbach har inddelt billederne af Kafkas liv i. Ifølge udgiveren kan bogen læses på to måder: "som en visuel skildring af en betydningsfuld forfatters liv i Prag og andre steder mellem 1883 og 1924. Eller som en refleksion over afstanden mellem den materielle baggrund og det litterære sprog" (7).

Wagenbachs bog er med til at forankre Kafka, hvis tekster som bekendt oftest kendetegnes ved ikke at referere til en identificerbar konkret realhistorisk virkelighed, i tid og rum - herunder et ophold på badehotellet Marielyst på Falster i juli 1914 efter ophævelsen af forlovelsen med Felice Bauer; Kafka sidder storsmilende i badebukser på stranden foran hotellet sammen med vennen Ernst Weiß og sendte et postkort til søsteren Ottla med teksten: "Det går mig forholdsvis godt." Eller et næsten surrealistisk fotografi fra februar 1922 af forfatteren i stiveste puds med hat og stok ved en hestekane i åbent landskab i snevejr på vej til Spindelmühle, hvor han påbegyndte Slottet. Vi får med dette pragtværk indsigt i den længe i receptionen udelukkede historiske, sociale og samfundsmæssige kontekst, han befandt sig i, og som hans værker blev til i. Det er således en påmindelse om, at alting må historiseres og kontekstualiseres, selv den gængse modernistisk ahistoriske Kafka. Lykkelig eller ej befandt også Kafka sig i en bestemt situation, i tid og sted.

Begge de her anmeldte udgivelser er fascinerende i ordets bedste betydning, vanskelige at lægge fra sig, og er begge vidnesbyrd om, at der til billedet af Kafka hører langt mere end depression og bortlængsel. 